\title{
Alternatives to antibiotics in diets of weaned piglets
}

\section{Soraia Viana Ferreira ${ }^{1}$ Lívia Maria dos Reis Barbosa ${ }^{1}$ Marcos Henrique Soares $^{1}$ Camila Schultz Marcolla ${ }^{1}$ Débora Muratori Holanda ${ }^{1}$ Alysson Saraiva ${ }^{2 *}$}

'Programa de Pós-graduação em Zootecnia, Universidade Federal de Viçosa (UFV), Viçosa, MG, Brasil.

${ }^{2}$ Departamento de Zootecnia, Universidade Federal de Viçosa (UFV), 36570-000, Viçosa, MG, Brasil. E-mail: alysson.saraiva@ufv.br.

${ }^{*}$ Corresponding author.

\begin{abstract}
This experiment was conducted to evaluate the effect of growth promoter additives an alternative to antibiotics on performance, intestinal morphology and on microbiota of 21-to-35-day-old piglets. A total of 160 commercial crossbred piglets (males and females) with initial weight of $6.10 \pm 0.709 \mathrm{~kg}$ were allotted in a completely randomized design with five treatments: Basal diet - Negative Control (NC); Basal diet + antibiotic $(P C) ;$ Basal diet + mannanoligosaccharides (MOS); Basal diet + organic acids $(O A)$, Basal diet + mannanoligosacharides + organic acids $(M O S+O A)$, eight replicates and four piglets per experimental unit. The inclusion of additives in the diets had no effect $(P>0.05)$ on the final average weight of piglets. Similarly, no effects $(P<0.05)$ were observed on average daily feed intake and on average daily weight gain. The feed conversion improved $(P<0.01)$ with the inclusion of additives in the diets compared to piglets fed with the NC. There was no effect $(P>0.05)$ of the dietary additives on intestinal morphology and microbiota composition (enterobacteria and lactobacilli). Use of antibiotics, prebiotics, organic acids or prebiotics associated with organic acids in the diet improves feed conversion of piglets from 21 to 35 days of age. The additives have no major effects on piglets 'intestinal morphology and microbiota.
\end{abstract}

Key words: additives, growth promoters, organic acids, prebiotics.

Alternativas de antibióticos para leitões desmamados

RESUMO: O experimento foi conduzido com o objetivo de avaliar o efeito de aditivos promotores de crescimento como alternativa ao uso de antibióticos no desempenho, na morfologia intestinal e na microbiota de leitões dos 21 aos 35 dias de idade. Um total de 160 leitões híbridos

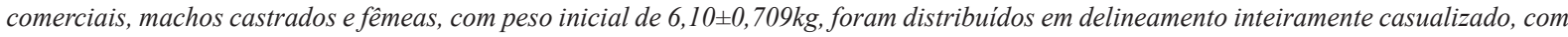
cinco tratamentos: Ração basal - Controle Negativo (CN); Ração basal + antibiótico (CP); Ração basal +mananoligossacarídeo (MOS); Ração basal + ácido orgânico (AO); Ração basal + mananoligossacarídeo + ácido orgânico (MOS+AO), oito repetições e quarto animais por unidade experimental. A inclusão dos aditivos não teve efeito $(P>0,05)$ no peso médio final dos leitões. Da mesma forma, não foram observados efeitos $(P>0,05)$ dos aditivos no consumo de ração médio diário. A conversão alimentar melhorou $(P<0,01)$ com a inclusão dos aditivos na ração comparados com os animais alimentados com a ração $C N$. Não houve efeito $(P>0,05)$ dos aditivos na morfologia do epitélio intestinal e na composição da microbiota (enterobactérias e lactobacilos). A utilização de antibiótico, probióticos, ácidos orgânicos ou de probióticos associado com ácidos orgânicos na ração melhora a conversão alimentar de leitões, dos 21 aos 34 dias de idade. Os aditivos não tiveram efeitos na morfologia intestinal e na microbiota dos leitões.

Palavras-chave: ácidos orgânicos, aditivos, probióticos, promotores de crescimento.

\section{INTRODUCTION}

In order to improve the growth rate of piglets after weaning, the use of antibiotics as growth-promoting agents through their inclusion in the diet at subtherapeutic doses has been done on a regular basis. Despite the proven ability to improve the performance of pigs, currently organizations linked to human health, governmental and nongovernmental organizations, among others, have sensitized public opinion, especially in developed countries, about the potential problems of continuous use of antibiotics in pigs' diets.

Therefore, with the increasing concern of governments and society about the possibility of bacterial resistance occurrence with the use of 
antibiotics in pig production, it is essential to look for dietary alternatives to be used in order to minimize the impact of the withdrawal from the production system of antibiotics as growth-promoter agents, and at the same time to ensure food safety for consumers.

Use of prebiotics and organic acids is among the strategies that have been developed to alleviate the negative effects of early weaning stressors. However, there have been few studies comparing the use of these alternatives under the same conditions (POEIKHAMPHA \& BUNCHASAK, 2011).

Therefore, this study aimed to evaluate the effects of using antibiotics, prebiotics and organic acids on performance, intestinal morphology, and microbiota composition of piglets from 21 to 35 days of age.

\section{MATERIALS AND METHODS}

A total of 160 commercial crossbred piglets (males and females) with initial weight of $6.10 \pm 0.709 \mathrm{~kg}$ were allotted in a completely randomized design with five treatments, eight replicates and four piglets per experimental unit represented by the cage $\left(0.40 \mathrm{~m}^{2} \mathrm{pig}^{-1}\right)$.

Temperature inside the nursery rooms was controlled by means of air conditioners to maintain it within the recommended thermal comfort zone. Environmental conditions inside the rooms were recorded daily (17:00) by maximum and minimum thermometers, black globe and dry bulb, and wet bulb $(8: 00,12: 00$, and 17:00), kept in an empty cage in the center of the room at half the height of the pigs' body. Recorded values were converted to the Black Globe Temperature and Humidity Index (BGHI, BUFFINGTON et al., 1981).

Experimental diets (Table 1) were formulated to meet the nutritional requirements of pigs in pre-initial phase (5.5 to $9 \mathrm{~kg}$ ), according to ROSTAGNO et al. (2011). Treatments were as follows: Basal diet - Negative Control (NC); Basal diet + antibiotic (PC); Basal diet + mannanoligosaccharides (MOS); Basal diet + organic acids (OA), Basal diet + mannanoligosacharides + organic acids (MOS+OA).

Piglets had free access to feed and water throughout the experimental period ( 21 to 35 days of age). Diets, leftovers and wastage were weighed periodically and piglets were weighed at 21 and 35 days of age (end of the experiment), to determine average daily feed intake (ADFI), average daily weight gain (ADG), and feed conversion $(F: G)$.

Temperature and relative humidity inside the nursery rooms during the trial period were $27.6 \pm 2.6^{\circ} \mathrm{C}$ and $54 \pm 9.6 \%$, respectively. Maximum and minimum temperatures were $29.8 \pm 1.3^{\circ} \mathrm{C}$ and $24.8 \pm 2.6^{\circ} \mathrm{C}$; respectively, and the BGHI calculated was $75.3 \pm 3.0$. A temperature of $26^{\circ} \mathrm{C}$ inside the nursery room, and a BGHI of 74.5 characterized a condition of thermal comfort zone for 6 to $15 \mathrm{~kg}$ piglets (NUNES et al., 2008). Thus, in the present study the piglets were not subjected to heat stress.

At 35 days of age, after fasting for 18h, one piglet per experimental unit, with a body weight closest to the average weight of the piglets from its respective cage was electrically stunned followed by exsanguination. Segments of $2.0 \mathrm{~cm}$ were sampled corresponding to duodenum ( $10 \mathrm{~cm}$ from the pylorus), jejunum (the middle portion of the intestine) and the ileum ( $5 \mathrm{~cm}$ from the ileo-caecal junction), according to YANG et al. (2014). Samples were opened by the mesenteric border, extended by serous layer, washed in saline solution, fixed in Bouin solution for 24 hours, and sent to the Histology Laboratory of Veterinary Medicine Department of the Universidade Federal de Viçosa to prepare the slides.

Histological sections were washed to remove the fixative solution, dehydrated in ethanol, diaphanized in xylene and embedded in paraffin. Two cuts of $5 \mu \mathrm{m}$ thickness each were placed in each slide. Slides were then placed in xylene solution again to remove excess of paraffin and hydrate. Dyes used were hematoxylin and eosin. After staining, the slides were dehydrated. For morphological readings, an optical microscope was used with 10x magnification, coupled to the image analyzer "Image-Pro Plus 1.3.1". Heights of 30 villi and their 30 crypts were selected and measured.

Samples of intestinal contents in the ileum were collected in sterile containers, immediately frozen, and sent to the Molecular Biology Laboratory of the Department of Microbiology of the Universidade Federal de Viçosa, for quantification of enterobacteria and lactobacilli.

The bacterial count was performed by PCR method in real-time (qRT-PCR). Reactions are performed using a 2x GoTaq $^{\circledR}$ qPCR Master Mix (Promega, Madison, WI, USA) in a detection system ABI PRISM 7300 sequence (Applied Biosystems, Foster City, CA, USA). For the amplification of 244bp and 126-bp16S rDNA fragments, the conditions were $10 \mathrm{~min}$ at $95^{\circ} \mathrm{C}, 40$ cycles of $15 \mathrm{~s}$ at $95^{\circ} \mathrm{C}$, and 1 min at $60^{\circ} \mathrm{C}$. All samples contained 5.0ng template DNA, and a set of specific primers (CASTILLO et al., 2006).

All data were analyzed in a complete randomized design, considering the initial body weight as covariate, using the GLM proc of SAS 9.4 (SAS 
Table 1 - Ingredient and nutritional composition of experimental diets fed to piglets from 21 to 35 days of age.

\begin{tabular}{|c|c|c|c|c|c|}
\hline Ingredient, \% & $\mathrm{NC}$ & $\mathrm{PC}$ & MOS & $\mathrm{OA}$ & $\mathrm{MOS}+\mathrm{OA}$ \\
\hline Corn & 42.851 & 42.851 & 42.851 & 42.851 & 42.851 \\
\hline Micronized Soybean & 18.000 & 18.000 & 18.000 & 18.000 & 18.000 \\
\hline Soybean meal & 17.000 & 17.000 & 17.000 & 17.000 & 17.000 \\
\hline Whey powder & 11.111 & 11.111 & 11.111 & 11.111 & 11.111 \\
\hline Blood plasma & 3.000 & 3.000 & 3.000 & 3.000 & 3.000 \\
\hline Soybean oil & 2.349 & 2.349 & 2.349 & 2.349 & 2.349 \\
\hline Dicalcium phosphate & 2.186 & 2.186 & 2.186 & 2.186 & 2.186 \\
\hline Kaolin & 1.150 & 1.075 & 0.990 & 0.800 & 0.640 \\
\hline Salt & 0.475 & 0.475 & 0.475 & 0.475 & 0.475 \\
\hline Limestone & 0.373 & 0.373 & 0.373 & 0.373 & 0.373 \\
\hline L-lysine & 0.374 & 0.374 & 0.374 & 0.374 & 0.374 \\
\hline Zinc oxide & 0.312 & 0.312 & 0.312 & 0.312 & 0.312 \\
\hline DL-methionine & 0.268 & 0.268 & 0.268 & 0.268 & 0.268 \\
\hline Vitamin premix $^{1}$ & 0.125 & 0.125 & 0.125 & 0.125 & 0.125 \\
\hline L-threonine & 0.175 & 0.175 & 0.175 & 0.175 & 0.175 \\
\hline Mineral premix ${ }^{2}$ & 0.125 & 0.125 & 0.125 & 0.125 & 0.125 \\
\hline L-tryptophan & 0.059 & 0.059 & 0.059 & 0.059 & 0.059 \\
\hline L-valine & 0.057 & 0.057 & 0.057 & 0.057 & 0.057 \\
\hline B-hydroxytoluene ${ }^{3}$ & 0.010 & 0.010 & 0.010 & 0.010 & 0.010 \\
\hline Organic acids ${ }^{4}$ & 0.000 & 0.000 & 0.000 & 0.350 & 0.350 \\
\hline Mannanoligasaccharide & 0.000 & 0.000 & 0.160 & 0.000 & 0.160 \\
\hline Growth promoter ${ }^{5}$ & 0.000 & 0.050 & 0.000 & 0.000 & 0.000 \\
\hline Growth promoter ${ }^{5}$ & 0.000 & 0.025 & 0.000 & 0.000 & 0.000 \\
\hline \multicolumn{6}{|c|}{ 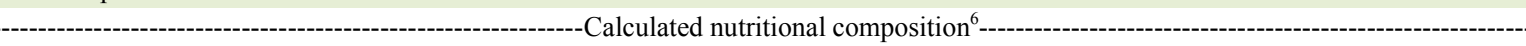 } \\
\hline Metabolizable energy, $\mathrm{kcal} / \mathrm{kg}$ & 3400 & 3400 & 3400 & 3400 & 3400 \\
\hline Crude protein, $\%$ & 18.85 & 18.85 & 18.85 & 18.85 & 18.85 \\
\hline Lactose, $\%$ & 8.000 & 8.000 & 8.000 & 8.000 & 8.000 \\
\hline Digestible lysine, \% & 1.450 & 1.450 & 1.450 & 1.450 & 1.450 \\
\hline Digestible met+Cys, \% & 0.812 & 0.812 & 0.812 & 0.812 & 0.812 \\
\hline Digestible threonine, $\%$ & 0.914 & 0.914 & 0.914 & 0.914 & 0.914 \\
\hline Digestible tryptophan, $\%$ & 0.261 & 0.261 & 0.261 & 0.261 & 0.261 \\
\hline Digestible valine, $\%$ & 1.000 & 1.000 & 1.000 & 1.000 & 1.000 \\
\hline Sodium, \% & 0.280 & 0.280 & 0.280 & 0.280 & 0.280 \\
\hline Calcium, \% & 0.850 & 0.850 & 0.850 & 0.850 & 0.850 \\
\hline Available phosphorus, $\%$ & 0.500 & 0.500 & 0.500 & 0.500 & 0.500 \\
\hline
\end{tabular}

${ }^{1}$ Content per kg of product: vitamin A $(5,500,000 \mathrm{UI})$, vitamin D3 (1,200,000UI), vitamin E (32,000UI), vitamin B1 (800mg), vitamin B2 $(2.5 \mathrm{~g})$, vitamin B5 $(1.6 \mathrm{~g})$, vitamin B12 (16mg), vitamin K3 $(2.4 \mathrm{~g})$, biotin $(80.0 \mathrm{mg})$, pantothenic acid $(12.0 \mathrm{~g})$, folic acid $(240.0 \mathrm{mg})$ and vehicle q.s.p. (1,000g). ${ }^{2}$ Content per kg product: Fe (64.0g), Cu (9.6g), Mn (32.0g), Zn (88.0g), I (800mg), Se (290mg) and vehicle q.s.p. $(1,000 \mathrm{~g}) .{ }^{3}$ Antioxidant. ${ }^{4}$ Lactic acid $35.3 \%$, formic acid $5.0 \%$. ${ }^{5}$ Content per kg of product: colistin $80,000 \mathrm{mg}$, and tylosin $400,000 \mathrm{mg}$. ${ }^{6}$ Calculated values according to ROSTAGNO et al. (2011).

Inst., Inc., Cary, NC). Means were compared using the Tukey test, excluding the NC. Dunnett test was used to compare the means of treatments containing the additives to the NC. A cage was considered the experimental unit for analysis of performance and one pig per cage was considered the experimental unit for analysis of intestinal morphology and microbiota. For all statistical procedures probability values less than 0.05 were considered significant.

\section{RESULTS AND DISCUSSION}

There was no effect $(\mathrm{P}>0.05)$ of additives on the average daily feed intake (ADFI) of piglets 
(Table 2). Similarly, SANCHEZ (2006) reported no effect on ADFI of piglets from 23 to 58 days of age fed diets containing antibiotics, probiotics (Bacillus subtilis), prebiotics (MOS), and symbiotic. In a study to assess the inclusion of sodium butyrate $(0.1,0.2$ and $0.4 \%$ ) in diets for pigs weaned at 28 days of age, ASSIS et al. (2014) evaluated diets containing mannanoligosaccharides (MOS), beta-glucans and antibiotics for gilts from 21 to 34 days of age and also reported no effect on ADFI.

Conversely, UTIYAMA et al. (2006) studying the effect of antimicrobials, MOS, probiotics (Bacillus subtilis and Bacillus licheniformis) or plant extracts in diets for pigs from 15 to 35 days of age, observed an increase in the ADFI of pigs fed with the diets supplemented with antimicrobials and prebiotics.

Inclusion of additives in the diet had no effect $(\mathrm{P}>0.05)$ on average daily weight gain $(\mathrm{ADG})$ of piglets (Table 2). Similarly, ROCA et al. (2014) in a study on the effect of antibiotics (avilamycin), organic acids (sodium butyrate), essential oils, and plant extracts in diets of piglets weaned at 20 days of age did not observe differences in ADG.

However, ZHAO et al. (2012), in a study with piglets from 21 to 35 days of age, reported the addition of MOS in the diet resulted in improved ADG compared to diet containing antibiotics and to the control diet.

There was an effect $(\mathrm{P}<0.05)$ on feed conversion $(\mathrm{F}: \mathrm{G})$ of piglets, with the use of additives (Table 2). Corroborating this result, CORASSA et al. (2012), studying the effectiveness of additives for piglets from 21 to 49 days, reported improved $F: G$ of piglets fed diets containing acidifiers, probiotics, antibiotics, MOS or a combination of MOS, acidifiers and probiotics compared to the control diet.
However, NÉVOA et al. (2013) reported no difference on the $F: G$ of 21 to 65 days of age piglets fed diets with antibiotics, probiotics (Saccharomyces cerevisae), or MOS. In a recent study with piglets from 22 to 43 days of age, SANTOS et al. (2016) reported that the control diet resulted in improved F:G compared to the diets containing probiotics (Bacillus subtillis), antibiotics or $\operatorname{MOS}(0.2 \%)$.

According to studies (HALAS et al., 2010; DIAO et al., 2014), improving feed efficiency may be appropriate to improving growth performance of piglets. In the present study, since the ADFI of piglets did not vary, or was numerically lower among the diets containing the additives compared to the $\mathrm{NC}$ diet, and a numerically increase on ADG from 5 to $14 \%$ of piglets fed with the diets containing the additives was observed, it can be inferred that possibly the additives altered the gain composition of the piglets. Thus, greater accretion of muscle tissue despite fat deposition may have occurred in piglets that consumed the diets containing additives. Increase in pig weight gain associated with improved feed conversion may be explained mainly by a higher accretion of protein tissue (KRICK et al., 1992).

No effect $(\mathrm{P}>0.05)$ for villous height (VH) was observed with the use of the additives (Table 3). Evaluating the effect of antibiotics and different inclusion levels of $\operatorname{MOS}(0.25 \%, 0.50 \%$, or $0.75 \%$ ) in the diets of piglets from 22 to 63 days of age, Santos et al. (2010) also observed no effect on VH. However, GHELER et al. (2009), in a study with benzoic acid $(0.25 ; 0.50$, or $0.75 \%)$, observed an increase in $\mathrm{VH}$ at all levels of inclusion compared to the control diet.

Table 2 - Performance of piglets from 21 to 35 days of age fed diets with different additives ${ }^{1}$.

\begin{tabular}{lccccccc}
\hline & & & & & & & \\
Factor
\end{tabular}

${ }^{1}$ Experimental diets: $\mathrm{NC}=$ negative control, $\mathrm{PC}=$ positive control, $\mathrm{MOS}=$ mannanoligosacharides, $\mathrm{OA}=$ organic acids, $\mathrm{MOS}+\mathrm{OA}=$ mananoligosaccharides + organic acids. ${ }^{2} \mathrm{IBW}=$ initial body weight, $\mathrm{FBW}=$ final body weight, $\mathrm{ADFI}=$ average daily feed intake, $\mathrm{ADG}=$ average daily gain, $\mathrm{F}: \mathrm{G}=$ feed conversion. ${ }^{3} \mathrm{IBW}$ was adopted as covariate in the analysis of variance for performance. * Means followed by an asterisk differ from the NC by Dunnett test at $5 \%$ probability. 
Table 3 - Intestinal morphology of piglets from 21 to 35 days of age fed diets with different additives ${ }^{1}$.

\begin{tabular}{|c|c|c|c|c|c|c|c|c|}
\hline \multirow{2}{*}{ Factor $^{2}$} & \multirow{2}{*}{$\mathrm{NC}$} & \multirow{2}{*}{$\mathrm{PC}$} & \multirow{2}{*}{ MOS } & \multirow{2}{*}{ OA } & \multirow{2}{*}{ MOS+OA } & \multicolumn{3}{|c|}{ 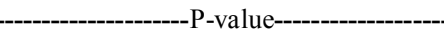 } \\
\hline & & & & & & Anova $^{3}$ & Dunnet & Tukey \\
\hline VH $(\mu \mathrm{m})$ & $240 \pm 13.83$ & $208 \pm 13.92$ & $237 \pm 12.90$ & $229 \pm 12.81$ & $245 \pm 13.83$ & 0.374 & 0.374 & 0.250 \\
\hline $\mathrm{CD}(\mu \mathrm{m})$ & $99 \pm 3.98$ & $87 \pm 4.40$ & $91 \pm 4.39$ & $89 \pm 3.98$ & $100 \pm 4.35$ & 0.192 & 0.192 & 0.245 \\
\hline $\mathrm{VH}(\mu \mathrm{m})$ & $186 \pm 9.98$ & $190 \pm 9.78$ & $187 \pm 9.04$ & $192 \pm 9.84$ & $188 \pm 9.76$ & 0.99 & 0.99 & 0.974 \\
\hline $\mathrm{CD}(\mu \mathrm{m})$ & $81 \pm 3.65$ & $77 \pm 3.33$ & $82 \pm 3.60$ & $73 \pm 3.63$ & $80 \pm 3.60$ & 0.395 & 0.395 & 0.377 \\
\hline $\mathrm{VH}(\mu \mathrm{m})$ & $141 \pm 11.27$ & $161 \pm 12.25$ & $145 \pm 13.34$ & $151 \pm 13.42$ & $145 \pm 13.38$ & 0.797 & 0.797 & 0.759 \\
\hline $\mathrm{CD}(\mu \mathrm{m})$ & $59 \pm 5.28$ & $60 \pm 4.94$ & $59 \pm 6.26$ & $54 \pm 5.32$ & $55 \pm 6.27$ & 0.892 & 0.892 & 0.867 \\
\hline
\end{tabular}

${ }^{1}$ Experimental diets: $\mathrm{NC}=$ negative control, $\mathrm{PC}=$ positive control, $\mathrm{MOS}=$ mannanoligosacharides, $\mathrm{OA}=$ organic acids, $\mathrm{MOS}+\mathrm{OA}=$ mananoligosaccharides + organic acids. ${ }^{2} \mathrm{VH}=$ villus height, $\mathrm{CD}=$ crypt depth, $\mathrm{V}: \mathrm{C}=$ villus height and crypt depth ratio. ${ }^{3}$ Initial body weight was adopted as covariate in the analysis of variance for intestinal morphology.

Dietary additives also did not influence $(\mathrm{P}>0.05)$ crypt depth $(\mathrm{CD})$ of the piglets (Table 3). Similar results were observed by SANCHES et al. (2006) and ASSIS et al. (2014), who evaluated the inclusion of prebiotics $\beta$-glucan, or antibiotics in diets for weaned piglets and also reported no effect on $\mathrm{CD}$ in the duodenum and jejunum of pigs. However, HU et al. (2013) observed shorter villus and deeper crypt on d 3 and 7 post-weaning, but according to these authors the damaged intestinal morphology was already recovered to preweaning values on day 14 post-weaning.

Percentage of enterobacteria and lactobacilli in the ileal digesta of piglets at 35 days of age was not influenced $(\mathrm{P}>0.05)$ by the additives (Table 4). According to this result, UTIYAMA et al. (2006) reported that diets containing antimicrobials, prebiotics, probiotics, or plant extracts for early weaned piglets were not effective in defining a specific microbiota profile for total microorganisms, total Gram-positive and Gramnegative bacteria.

However, CASTILLO et al. (2006) detected a significant increase in the number of lactobacilli in the cecum of pigs fed a diet enriched with plant extracts. However, in this same study, no differences in the amount of enterobacteria, either in animals fed with a diet enriched with sodium butyrate, enriched with plant extracts or containing antibiotics were reported. According to CANIBE et al. (2005), these results indicated that these additives may produce qualitative changes on the bacterial population of the gastrointestinal tract without affecting the total amount of bacteria.

Table 4 - Percentage of enterobacteria and lactobacilli in ileal digesta of piglets at 35 days of age fed with different additives ${ }^{1}$.

\begin{tabular}{|c|c|c|c|c|c|c|c|c|}
\hline \multirow{2}{*}{ Factor $^{2}$} & \multirow{2}{*}{$\mathrm{NC}$} & \multirow{2}{*}{$\mathrm{PC}$} & \multirow{2}{*}{ MOS } & \multirow{2}{*}{$\mathrm{OA}$} & \multirow{2}{*}{$\mathrm{MOS}+\mathrm{OA}$} & \multicolumn{3}{|c|}{-----------------P-Value--------------- } \\
\hline & & & & & & Anova $^{3}$ & Dunnet & Tukey \\
\hline Enterobacteria & $0.10 \pm 0.066$ & $0.12 \pm 0.072$ & $0.10 \pm 0.072$ & $0.11 \pm 0.072$ & $0.33 \pm 0.072$ & 0.087 & 0.087 & 0.197 \\
\hline Lactobacilli & $19.0 \pm 3.15$ & $21.3 \pm 2.91$ & $21.1 \pm 2.66$ & $23.0 \pm 2.68$ & $15.55 \pm 2.68$ & 0.359 & 0.359 & 0.290 \\
\hline
\end{tabular}

${ }^{1}$ Experimental diets: $\mathrm{NC}=$ negative control, $\mathrm{PC}=$ positive control, $\mathrm{MOS}=$ mannanoligosacharides, $\mathrm{OA}=$ organic acids, $\mathrm{MOS}+\mathrm{OA}=$ mananoligosaccharides + organic acids. ${ }^{2}$ Results represent the percentage of the target species (enterobacteria and lactobacilli) in the ileal digesta samples compared to the total bacterial content of the samples. Target for quantification was the gene coding 16S rRNA of each group examined. ${ }^{3}$ Initial body weight was adopted as covariate in the analysis of variance for intestinal microbiota. 


\section{CONCLUSION}

The use of antibiotics, prebiotics, organic acids or prebiotics associated with organic acids in the diet improves feed conversion of piglets from 21 to 35 days of age. The additives have no major effects on piglets' intestinal morphology and microbiota.

\section{ACKNOWLEDGMENTS}

To the Fundação de Amparo à Pesquisa do Estado de Minas Gerais (FAPEMIG), Coordenação de Apoio de Pessoal de Nível Superior (CAPES), and to the Instituto Nacional de Ciência e Tecnologia e Tecnologia de Ciência Animal (INCT-CA) for financial support.

\section{BIOETHICS \\ AND \\ BIOSECURITY COMMITTEE APPROVAL}

All procedures involving animal handling were done in accordance with regulations approved by the Institutional Ethic Committee of Animals Production Use (CEUAP-UFV) from the Universidade Federal de Viçosa, Brazil.

\section{REFERENCES}

ASSIS, S.D. et al. Desempenho e características morfo-intestinais de leitoas desmamadas alimentadas com dietas contendo associações de mananoligossacarídeo. Archives of Veterinary Science v.19, p.33-41, 2014. Available from: <http://revistas.ufpr. br/veterinary/article/view/35581>. Accessed: Jan. 19, 2017.

BUFFINGTON, D.E. et al. Black globe-humidity index (BGHI) as comfort equation for dairy cows. Transaction of the ASAE, v.24, p.711-714, 1981.

CANIBE, N. et al. Feed physical form and formic acid addition to the feed affect the gastrointestinal ecology and growth performance of growing pigs. Journal of Animal Science, v.83, p.1287-1302, 2005. Available from: <https://www.ncbi.nlm.nih. gov/pubmed/15890806>. Accessed: Dec. 10, 2016.

CASTILLO, M. et al. The response of gastrointestinal microbiota to avilamycin, butyrate, and plant extracts in early-weaned pigs. Journal of Animal. Science, v.84, p.2725-2734, 2006. Available from: $<$ https:// www.ncbi.nlm.nih.gov/pubmed/16971574>. Accessed: Jan. 20, 2017.

CORASSA, A. et al. Mananoligossacarídeos, ácidos orgânicos e probióticos para leitões de 21 a 49 dias de idade. Archivos de Zootecnia, v.61, p.467-476, 2012. Available from: <http://scielo. isciii.es/pdf/azoo/v61n235/art15.pdf>. Accessed: Feb. 15, 2017.

DIAO, H. et al. Effects of dietary supplementation with benzoic acid on intestinal morphological structure and microflora in weaned piglets. Livestock Science, v.167, p.249-256, 2014. Available from: $<$ http://www.livestockscience.com/article/S18711413(14)00301-1/pdf>. Accessed: Feb. 20, 2017.

GHELER, T.R. et al. Use of benzoic acid in the diet of piglets. Revista Brasileira de Zootecnia, v.38, p.2182-2187, 2009. Available from: <http://www.scielo.br/pdf/rbz/v38n11/a16v3811. pdf>. Accessed: Dec. 15, 2016.
HALAS, D. et al. Effects of benzoic acid and inulin on ammonianitrogen excretion, plasma urea levels, and the $\mathrm{pH}$ in faeces and urine of weaner piglet. Livestock Science, v.134, p.243-245, 2010. Available from: < http://www.livestockscience.com/article/S18711413(10)00365-3/pdf>. Accessed: Jan. 10, 2017.

HU, C.H. et al. Early weaning increases intestinal permeability, alters expression of cytokine and tight junction proteins, and activates mitogen-activated protein kinases in pigs. Journal of Animal Science, v.91, p.1094-1101, 2014. Available from: $<$ https://www.ncbi.nlm.nih.gov/pubmed/23230104>. Accessed: Mar. 5, 2017. doi: 10.2527/jas.2012-5796.

KRICK, B.J.; BOYD, R.D. Influence of genotype and sex on the response of growing pigs to recombinant porcine somatotropin. Journal of Animal Science, v.70, p.3024, 1992. Available from: $<$ https://www.ncbi.nlm.nih.gov/pubmed/1429279>. Accessed: Nov. 25, 2016 doi: 10.2527/1992.70103024x

NÉVOA, M.L. et al. Desempenho e características bioquímicas de leitões submetidos a dietas com aditivos probióticos, prebióticos, simbióticos e antibióticos. Arquivos Brasileiros de Medicina Veterinária e Zootecnia, v.65, p.447-454, 2013. Available from: $\quad<$ http://www.scielo.br/scielo.php?script=sci_arttext\&pid =S0102-09352013000200021>. Accessed: Feb. 10, 2017.

POEIKHAMPHA, T.; BUNCHASAK, C. Comparative effects of sodium gluconate, mannan oligosaccharide and potassium diformate on growth performances and small intestinal morphology of nursery pigs. Asian-Australasian Journal of Animal Sciences, v.24, p.844-850, 2011. Available from: <http://ocean.kisti.re.kr/ downfile/volume/aaaaps/E1DMBP//v24n6/2011_v24n6_844. pdf>. Accessed: Jan. 20, 2017.

ROCA, M. et al. Changes in bacterial population of gastrointestinal tract of weaned pigs fed with different additives. BioMed Research International, v.2014, p.1-13, 2014. Available from: $<$ http://www.hindawi.com/journals/bmri/2014/269402/>. Accessed: Feb. 15, 2017.

ROSTAGNO, H.S. et al. Tabelas brasileiras para aves e suínos: composição de alimentos e exigências nutricionais. 3.ed. Viçosa, MG: UFV, Imprensa Universitária, 2011. 290p.

SANCHES, A.L. et al. Utilização de probiótico, prebiótico e simbiótico em rações de leitões ao desmame. Ciência Agrotécnica, v.30, p.774-777, 2006. Available from: <http://www.scielo.br/ scielo.php?script $=$ Sci_arttext\&pid $=\mathrm{S} 1413-70542006000400026>$. Accessed: Dec. 15, 2016.

SANTOS, A.V. et al. Aditivos antibiótico, probiótico e prebiótico em rações para leitões desmamados precocemente. Ciência Animal Brasileira, v.17, p.1-10, 2016. Available from: <http:// www.scielo.br/pdf/cab/v17n1/1809-6891-cab-17-01-0001.pdf $>$. Accessed: Jan. 20, 2017.

SANTOS, V.M. et al. Digestibilidade, desempenho e características morfofisiológicas do trato digestório de leitões desmamados sob dietas com mananoligossacarídeo. Pesquisa Agropecuária Brasileira, v.45, p.91-105, 2010. Available from: $<$ http://www.scielo.br/scielo.php?script=sci_arttext\&pid=S0100204X2010000100013>. Accessed: Nov. 25, 2016.

UTIYAMA, C.E. et al. Efeitos de antimicrobianos, prebióticos, probióticos e extratos vegetais sobre a microbiota intestinal, a frequência de diarreia e o desempenho de leitões recém 
desmamados. Revista Brasileira de Zootecnia, v.35, p.23592367, 2006. Available from: <http://www.sbz.org.br/revista/ artigos/4616.pdf $>$. Accessed: Nov. 25, 2016.

YANG, K.M. et al. Effect of Lactobacillus plantarum on diarreia and intestinal barrier function of young piglets challenged with enterotoxigenic Escherichia coli K88. Journal of Animal Science, v.92, p.1496-1503, 2014. Available from: $\quad<$ https://www.ncbi.nlm.nih.gov/pubmed/24492550> Accessed: Jan. 10, 2017.

ZHAO, P.Y. et al. Effect of mannanoligosaccharides and fructan on growth performance, nutrient digestibility, blood profile, and diarrhea score in weanling pigs. Journal of Animal Science, v.90, p.833-839, 2012. Available from: <https://www.ncbi.nlm.nih.gov/ pubmed/21984718>. Accessed: Nov. 25, 2016. 